\title{
The Geographic Scope of Retail Deposit Markets
}

\author{
Erik Heitfield \\ Federal Reserve Board \\ Mail Stop 153, Washington, DC 20551 \\ (202) 452-2613 \\ Erik.Heitfield@frb.gov \\ Robin A. Prager \\ Federal Reserve Board \\ Mail Stop 149, Washington, DC 20551 \\ (202) 452-3643 \\ Robin.Prager@frb.gov
}

August 13, 2002

The views expressed in this paper are those of the authors and do not necessarily reflect the views of the Board of Governors of the Federal Reserve System or its staff. The authors thank Dean Amel, Tim Hannan, Beth Kiser, Steve Pilloff and John Wolken for valuable comments and suggestions. Paul Tan and Charles Taragin provided outstanding research assistance. 


\begin{abstract}
:
In the United States, antitrust authorities rely heavily on numerical measures of local banking market concentration such as the Herfindahl Hirschmann Index to assess the likely competitive effects of proposed bank mergers and acquisitions. This approach to antitrust enforcement relies on two important assumptions: (1) that markets for at least some types of banking products are local in scope, and (2) that market concentration measures can serve as effective proxies for banks' abilities to extract monopoly rents. This paper uses balance sheet data from most banks operating in the United States in 1988, 1992, 1996, and 1999 to test these assumptions. We test the assumption that banking markets are local in scope by looking for systematic cross-market differences in the interest rates paid on retail deposit products. We find strong evidence that the geographic scope of markets for NOW accounts did not expand beyond local market boundaries in the 1990s, but we can neither confirm nor reject the hypothesis of a broadening in scope of markets for MMDA and savings accounts. We test the assumption that concentration measures are related to deposit account interest rates using a number of different regression model specifications. Local concentration measures are strongly negatively related to interest rates paid on NOW and savings accounts in nearly all model specifications. The results are somewhat weaker for MMDA accounts, but we still find significant negative relationships in some model specifications in all years. State-level concentration measures are negatively related to deposit interest rates offered on NOW and money market accounts, even in those cases where there is strong evidence that markets are smaller than statewide. This suggests that the simple structure-conductperformance paradigm in which local market concentration alone drives pricing power may be too simplistic.
\end{abstract}




\section{Introduction}

In the United States, the Department of Justice and bank regulatory authorities (the Federal Reserve Board, the Federal Deposit Insurance Corporation, or the Office of the Comptroller of the Currency) have joint responsibility for assessing the competitive implications of proposed bank mergers and acquisitions. The relevant bank regulator must determine that a proposed transaction will not have a significantly adverse effect on competition before the deal can be consummated. The Justice Department has the option to challenge the proposed transaction in court if it independently concludes that the merger or acquisition is likely to result in a significant increase in market power. Because of the large number of bank mergers proposed each year, both bank regulators and the Justice Department make use of simple numerical market concentration measures to identify mergers that are likely to raise competitive concerns. This screening approach explicitly relies on two important assumptions: (1) markets for at least some banking product lines are local in scope, and (2) deposit market shares and deposit-based Herfindahl concentration measures (HHIs) are effective proxies for banks' abilities to extract monopoly rents in those product lines. The two assumptions are intertwined because the geographic scope of banking markets determines how bank market shares and Herfindahl concentration measures are calculated.

The assumptions underpinning the use of local market HHIs to assess the likely competitive impact of a proposed bank merger are supported by an extensive body of empirical evidence. Analysis of household and small business survey data by Kwast, Starr-McCluer and Wolken (1997) and, more recently, by Amel and Starr-McCluer (2002) shows that retail banking customers overwhelmingly obtain their deposit services from banks that operate nearby offices. Because these studies examine only equilibrium behavior and do not explore how consumers respond to price differences, they do not provide definitive evidence that markets are local. However consumers' strong apparent preference for local banks is highly suggestive that retail banking markets are locally limited. Studies of bank pricing behavior by Berger and Hannan (1989), Calem and Carlino (1991), and Hannan (1997) all find negative relationships between measures of 
local market concentration, including the HHI, and interest rates paid to depositors. While correlation does not necessarily imply causation, these findings are generally interpreted as supportive of the view that local concentration measures are good proxies for bank market power.

Radecki (1998) argues that changes in technology and/or consumer preferences may have broadened the scope of retail banking markets in recent years, implying that local concentration measures are no longer appropriate for use in banking antitrust analysis. Using data on deposit interest rates offered in a sample of urban markets, Radecki shows that banks that operate branches throughout a state frequently offer the same deposit interest rates in a number of metropolitan areas within that state. He interprets this failure to price discriminate across local markets as evidence that deposit markets may actually be statewide in scope. Using very similar data, Heitfield (1999) confirms Radecki's empirical finding for statewide banks, but also finds significant crosscity differences in the interest rates paid on comparable deposit products when both statewide banks and banks that operate in a single metropolitan area are taken into account. Heitfield interprets this result as suggesting that statewide banks may choose not to price discriminate across local areas for reasons unrelated to an expansion of geographic market boundaries. A difficulty with both studies is that they focus on the largest banks in selected urban markets. They ignore many smaller banks operating in urban markets, and all banks operating in rural markets. Rural markets tend to be much more highly concentrated than urban markets, and consequently tend to receive disproportionate attention from antitrust authorities.

This paper assesses the usefulness of local concentration measures in antitrust analysis by applying techniques similar to those employed by Radecki (1998) and Heitfield (1999) to a much larger sample of banks covering a broader range of markets and time periods. We achieve our large sample size by using data on interest expenses and deposit account balances to construct average interest rate measures for NOW accounts, money market deposit accounts, and savings accounts offered by most banks operating in the United States in 1988, 1992, 1996, and 1999. Section 2 explains how our interest rate measures were constructed and discusses some of the advantages and disadvantages of using them. 
Section 3 tests the hypothesis that geographic markets are statewide in scope against the alternative that they are more narrowly defined by looking for systematic differences in interest rates paid on comparable deposit products in different local markets within a state. A finding of significant interest rate differences indicates that comparable deposit products offered in different localities within a state cannot be close substitutes for one another and therefore cannot lie in a single statewide geographic market. Our findings suggest that geographic markets for NOW accounts remain local, but that the geographic scope of markets for money market deposit accounts and savings accounts may have broadened over the last decade.

If retail banking markets are indeed local, and there is a relationship between market concentration and pricing power, then we should observe an inverse relationship between local market concentration measures and deposit interest rates. In the same study discussed earlier, Radecki suggests that this relationship may have weakened during the 1990s. Using 1996 data, Radecki finds no evidence of a significant relationship between local market concentration and deposit interest rates, but does find a significant negative relationship between state level concentration measures and deposit interest rates. Section 4 explores this issue more fully. We find that the relationship between local market concentration and deposit interest rates has not weakened over time for NOW accounts, MMDA accounts, or savings accounts. We also find evidence of a negative relationship between state level concentration measures and deposit interest rates for both NOW accounts and MMDA accounts, which appears to have strengthened considerably during the 1990s. The latter finding raises some interesting policy questions that are discussed in Section 5.

\section{Interest Rate Data}

Banks offer a variety of financial products to their retail customers, including mortgages and home equity loans, auto loans, credit cards, and several different types of deposit accounts. For most retail loan products, prices depend on customer-specific characteristics, such as credit rating and income, which cannot easily be observed by outside researchers. In contrast, interest rates and fees for deposit products do not 
generally reflect customer-specific characteristics. Given that the focus of our analysis is the relationship between observable market characteristics and the prices offered by banks operating in those markets, it is important that we be confident that observed price differences across markets do not simply reflect unobserved differences in the composition of customers in different markets. For this reason, our analysis focuses on interest rates paid on relatively homogeneous classes of interest-bearing deposit accounts: NOW accounts, money market deposit accounts (MMDAs), and savings accounts. ${ }^{1}$

We use data obtained from the quarterly Reports of Condition and Income (Call and Income Reports) to construct a bank-level average interest rate measure for each account type. To understand why we chose to use Call and Income Report data, it is helpful to briefly consider the two available alternative sources of information on retail deposit rates: the Federal Reserve's Monthly Survey of Selected Deposits, and Bank Rate Monitor, Inc.'s deposit rate survey.

The Monthly Survey of Selected Deposits (MSSD) has been used as a source of data on deposit interest rates in numerous studies, including Berger and Hannan (1989), Calem and Carlino (1991), and Prager and Hannan (1998). Prior to October 1994, this survey reported actual interest rates offered on various types of deposit accounts, as of a specific day each month, by a sample of approximately 500 banks. Beginning in October 1994, the Federal Reserve modified the survey questionnaire and began collecting information on total interest expenses associated with each type of account during the month and outstanding balances as of the last day of the month. This information was then used to compute an interest rate measure for each type of account at each bank. This change in the survey questionnaire renders the use of this data source for comparisons of bank pricing behavior before and after 1994 inappropriate. In 1997, the Federal Reserve discontinued the MSSD.

More recently, Radecki (1998) and Heitfield (2000) have used survey data collected by Bank Rate Monitor, Inc. (BRM), a private market research firm. In contrast to the MSSD, the BRM data provides information on interest rates paid in specific urban areas. Thus, a single bank may report rates for several different urban areas in which it

\footnotetext{
${ }^{1}$ Ideally, we would like to take into account the entire fee structure associated with a particular type of account in constructing our price measures. Unfortunately, fee data are not available for different types of
} 
operates. Every week, BRM surveys ten banks or thrifts operating in each of 112 metropolitan statistical areas. ${ }^{2}$ The main disadvantage of the BRM survey is that it includes no information on rates paid in rural markets, where antitrust problems are most likely to arise.

Because all banks with branches in the United States must file Call and Income Reports every quarter, these data can provide information on interest rates paid by a much broader range of banks, operating in many more geographic regions than the BRM survey, over a longer time period than the MSSD. In principle, Call and Income Report data could be used to infer average interest rates paid on deposit accounts for every bank in the country in any quarter. In practice, however, reporting irregularities and changes in accounting practices over time render data for some banks at some dates unusable.

In this study we use Call and Income Report data to construct bank-level average interest rates for each of three types of deposit accounts: NOW accounts, money market deposit accounts, and savings accounts. We begin by dividing a bank's quarterly expenses associated with each type of account by the average of the current quarter's and previous quarter's end-of-quarter account balances. ${ }^{3}$ We then calculate the annual interest rate for each year as the annualized geometric mean of the quarterly interest rates. Finally, observations in the top percentile and bottom percentile are dropped. ${ }^{4}$ Summary statistics for the imputed interest rate data are presented in Table 1.

\section{Regional Price Correlations}

The geographic scope of any good or service market depends on the extent to which consumers are willing to substitute similar products sold at different locations for

\footnotetext{
deposit accounts, so we are not able to make the appropriate adjustments.

${ }^{2}$ BRM's Weekly Interest data set includes firms selected from the 100 largest metropolitan markets plus 12 additional markets (one from each state that is not represented in the top 100).

${ }^{3}$ Prior to doing these calculations, we screen the expense and account balance data to eliminate implausible or erroneous values. First, we eliminate any observations for which the quarterly account expenses are negative or the end of quarter account balances are less than or equal to zero, since these are implausible values. Second, we eliminate any observations where the reported expenses for the quarter are less than 25 percent or more than 400 percent of the previous quarter's value, on the assumption that such dramatic changes from one quarter to the next are likely to indicate reporting errors or changes in accounting practices.
} 
one-another. Ideally, therefore, an empirical study of market definition should measure the importance of product location versus other differences in product characteristics (including price) in determining how consumers choose among competing alternatives. Unfortunately, such studies require very detailed data on prices and quantities and/or very strong assumptions about the behavior of producers and consumers. In banking, detailed quantity data are difficult to come by and exogenous changes in product prices are nearly impossible to identify. Fortunately, in the absence of detailed information on supply and demand conditions, price data alone can provide enough information to test simple hypotheses relating to the geographic scope of markets.

Within a geographic market, both producers and consumers should view goods with similar attributes as close substitutes for one another, and market forces should act to equilibrate the prices of these goods. On the other hand, if similar goods lie in different geographic markets, they must be imperfect substitutes and their prices may differ substantially from market to market. Thus, a finding that the prices of goods with similar observable characteristics (i.e., members of the same product market) differ significantly across regions provides strong evidence that those regions constitute separate geographic markets.

Importantly, while regional price differences can rule out larger geographic markets, the opposite is not true. Similarities in prices across regions do not imply that those regions are part of the same geographic market. For example, a cup of coffee in Berkeley, California and a cup of coffee in Washington, D.C. each cost about a dollar, but no one would argue that these two goods are close substitutes. Similarly, two deposit accounts offered in different regions may pay similar interest rates because of coincident supply and demand conditions, even though neither consumers nor producers treat these accounts as substitutes. Alternatively, even when local supply and demand conditions would lead to different equilibrium prices in two regions, a firm that operates in both regions may decide to charge the same prices in both regions because it believes that the costs of determining and maintaining different prices would exceed the benefits. Thus, taken by themselves, price data can only be used to test hypotheses in one direction.

\footnotetext{
${ }^{4}$ Our screening process eliminated approximately six percent of the initial observations for each account type in each year.
} 
They can provide evidence to reject hypotheses that geographic markets are "large", but they cannot provide evidence to reject hypotheses that markets are "small".

If each bank operated in a single, narrow geographic region such as an MSA or a county, constructing price-based geographic market definition tests from available banklevel price data would be a simple matter. One could think of each bank's average interest rate as being comprised of a market-specific component and a bank-specific component. The former would reflect the competitive conditions prevailing in the local market in which the bank operates, and the latter would reflect the characteristics of the products or services offered by that particular bank. In a world of single-market banks, one could regress bank-level interest rates on a set of local market dummy variables and a vector of bank characteristics, and test the hypothesis that the coefficients on all of the local market dummies within a state were the same. Rejection of this hypothesis would indicate that, after controlling for bank characteristics, deposit interest rates offered on a particular type of account differed across local areas within a state. Such a finding would provide empirical support for the local geographic market assumption that underlies current antitrust policy towards the banking industry.

In a world in which banks may operate in more than one narrow geographic region, there is no longer a clear correspondence between bank-level average interest rates and the average rates charged in individual regions. The most straightforward way to deal with this problem is to simply restrict attention to "locally based" banks whose deposit-gathering operations are heavily concentrated in a single metropolitan area or rural county. ${ }^{5}$ In the current context, this approach has two shortcomings. First, it requires that we throw out a great deal of useful price data from geographically diversified banks. Second, and more importantly, it is likely to present an inaccurate picture of inter-regional price differences if locally based banks behave differently from other banks, or if consumers view their services as qualitatively different from those provided by larger, more diversified, banks.

This analysis makes use of an alternative approach that does not suffer from these shortcomings. We assume that a multimarket bank's average deposit interest rate

\footnotetext{
${ }^{5}$ This approach has been used in other contexts by a number of researchers. See, for example, Berger and Hannan (1989), Pilloff and Rhoades (2002).
} 
depends, among other things, on a deposit-weighted average of the market conditions prevailing in all of the markets from which the bank derives its deposits. This assumption implies that the average interest rate offered by bank $i, r_{i}$, can be described by the linear regression model

$$
r_{i}=\sum_{m=1}^{M} s_{i m} \rho_{m}+X_{i} \beta+\varepsilon_{i}
$$

$s_{i m}$ is the share of bank $i$ 's total deposits held in market $m$. If all banks were locally based, $s_{i 1}$ through $s_{i M}$ would be market dummy variables, but because some banks operate in more than one area these variables are shares that sum to one for each bank. $X_{i}$ is a vector of bank-specific characteristics that are believed to influence the interest rates paid on deposits. This vector is included to allow for the possibility that deposit services offered by some types of banks are imperfect substitutes for the services offered by other types of banks. For example, some customers may be willing to pay a premium for the type of individualized service that they receive at a small, local bank, whereas others may appreciate the scope of services available from a larger, nationwide bank. ${ }^{6}$

The parameters $\rho_{1}$ through $\rho_{M}$ capture the effect of the geographic distribution of a bank's deposits on its average interest rate. If all local markets (MSAs and rural counties) within a state are part of the same geographic retail banking market, then the location of deposits should not matter and we should not be able to reject the hypothesis that $\rho_{1}=\rho_{2}=\ldots \rho_{M}$ within that state. A finding of significant differences in local effects within a state provides strong evidence against the hypothesis that all $M$ localities lie in the same statewide geographic market. However, for reasons discussed earlier, failure to find such differences need not imply that banking markets are statewide in scope.

Equation (1) is estimated separately for each account type, state, and year, for each of the ten most populous states. ${ }^{7}$ For some states, the total number of metropolitan areas and rural counties, and therefore the number of market effects, is quite large. Collinearity problems arise when two local markets are served by the same set of banks

\footnotetext{
${ }^{6}$ The natural logarithm of bank assets or holding company assets, and a dummy indicating whether or not the bank is a member of a holding company were included as bank-specific variables in the interest rate regressions. Regressions without bank-specific variables were also run, and produced similar results. ${ }^{7}$ These states are California, Florida, Georgia, Illinois, Michigan, New Jersey, New York, Ohio, Pennsylvania, and Texas.
} 
and each of the banks derives approximately the same share of its deposits from each market (i.e, two of the local market variables are highly correlated with each other). To deal with this problem, we exclude from our analysis a small number of market pairs. Separate analyses are undertaken for samples that include all local markets (urban and rural) within each state, and restricted samples containing only urban areas. The latter samples were used to examine the possibility that urban markets may be more closely integrated with one-another than with rural markets in the same state.

We examine within-state differences in local interest rate effects in two stages. First we test the restriction $\rho_{1}=\rho_{2}=\ldots=\rho_{M}$ to determine whether observed differences are statistically significant. We then examine characteristics of the distributions of the local average interest rate effects to get a sense of whether those differences that are statistically significant are also economically meaningful. Tables 2 through 7 present results for three account types (NOW accounts, MMDAs, and savings accounts), in each of four years (1988, 1992, 1996, and 1999), using both the full samples of markets and the restricted samples of only urban markets. ${ }^{8}$ The columns labeled "F-test Statistic" show the test statistics calculated for the parameter restriction that all local interest rate effects are the same within a state. The columns labeled "F-test P-value" report the probability that a number greater than the F-statistic would be generated from random data, assuming the null hypothesis of equal rates were true. A value in this column of less than 0.05 indicates that the corresponding null hypothesis is rejected at the five percent significance level. The next three columns report percentiles of the distributions of estimated local interest rate effects in each state, and the last column reports the interquartile range (the difference between the $75^{\text {th }}$ and $25^{\text {th }}$ percentiles). Percentiles and interquartile ranges are reported rather than more common summary statistics such as means and variances, because they are more robust to spurious results that arise from multicollinearity problems in some regressions. ${ }^{9}$

\footnotetext{
${ }^{8}$ As a robustness check, the analysis was also conducted using a restricted sample of banks that derive at least 80 percent of their deposits from a single local area. The results from this analysis (not reported here) were quite similar to those from the full sample analysis.

${ }^{9}$ This problem does not have a material effect on the F-tests because the spurious rate measures are generated with considerable imprecision and are therefore given very little weight in the calculation of the test statistics.
} 
The results for NOW accounts are presented in Tables 2 and 3. We can reject the statewide markets hypothesis at the 95 percent confidence level for several states in each year. Looking at the results for all markets (Table 2), we find statistically significant differences in local market effects in 1999 for Florida, Georgia, Illinois, Ohio, and Texas. For every state except Illinois, the interquartile range for local market effects in 1999 exceeded fifty basis points. Local market effects can be roughly interpreted as local average interest rates, so these interquartile ranges are quite substantial. Although the overall level of NOW account interest rates declined during the 1988 to 1999 period (see Table 1), there is no evidence that local differences in these rates have become less important. Indeed the dispersions in local market effects have grown steadily between 1988 and 1999. These results suggest that the geographic boundaries of NOW account markets have not expanded over time, and that markets for NOW accounts are better described by rural counties and MSAs than by entire states. Similar conclusions can be drawn when only urban markets are considered.

F-tests for Money Market Deposit Accounts generally reject the statewide markets hypothesis in all years except 1999. As can be seen in Table 4, when both urban and rural markets are considered, we find statistically significant differences in local effects in five of ten states in 1988, eight of ten states in 1992, five of ten states in 1996, but only two of ten states in 1999. Similar patterns can also be observed in the urban markets sample. Despite the fact that differences in local market effects appear to have become less statistically significant in recent years, the dispersion in these effects as measured by their interquartile ranges has not diminished over time for any state and has increased substantially in most cases. This suggests that bank-to-bank differences in MMDA interest rates have increased both across and within markets, a finding that is consistent with increased product differentiation across banks.

Results for savings accounts are mixed. As Table 6 shows, statistically significant differences in local market effects exist in some states in some years, but no obvious trends can be observed. Although the interquartile ranges of local market effects are widest for many states in 1999, differences in these ranges over time are less pronounced than for other types of accounts. Similar results are obtained when only urban markets are considered (Table 7). Overall, the evidence against the statewide markets hypothesis 
is weaker for savings accounts than it is for NOW and money market accounts. These results are consistent with the interpretation that geographic markets for checkable, transaction-oriented accounts that involve frequent interaction with local bank branches are narrower in scope than those for longer-term savings products.

\section{Price-Concentration Relationship}

In this section, we consider the relationship between deposit interest rates and concentration, measured at both the local market level and the state level, using data from 1988, 1992, 1996 and 1999. Following the previous literature, we estimate linear regression models in which the dependent variable is the deposit interest rate offered by a given bank on a particular type of deposit account, and the right hand side variables include a measure of local market concentration, bank characteristics, and market characteristics.

Our analysis differs from previous work in two important ways. First, as explained in Section 2 above, we employ a data source that provides consistent measures of deposit interest rates over time for a very large number of banking organizations. Second, in addition to local market variables, we include state level concentration measures and state characteristics in each regression. This enables us to determine both whether the relationship between local market concentration and deposit interest rates has changed over time and whether the relationship between state level concentration and deposit interest rates has changed over time.

A potential problem afflicting this and previous studies of the relationship between local market concentration and prices derives from the fact that local market concentration is strongly negatively correlated with market size. For this reason, estimating a price-concentration relationship for a sample that includes banking organizations operating in both urban and rural markets may confound the effects of market size or other differences between urban and rural markets with the effects of concentration. To deal with this potential problem, we estimate separate regressions using both the full sample of banking organizations and a sub-sample that includes only those banks that derive more than half of their deposits from urban markets. 
The following regression model is estimated for each of the three deposit account types included in our analysis:

$$
\begin{aligned}
& r_{i}=\beta_{0}+\beta_{1} \text { MKTCONC }_{i}+\beta_{2} \text { STATECONC }_{i}+\beta_{3} \text { LOG }_{\left(\text {ASSETS }_{i}\right)} \\
& +\beta_{4} L O G\left(\text { MKTPOP }_{i}\right)+\beta_{5} L O G\left(\text { STATEPOP }_{i}\right)+\beta_{6} \text { MKTPCI }_{i} \\
& +\beta_{7} \text { STATEPCI }_{i}+\beta_{8} \text { MKTGROWTH }_{i}+\beta_{9} \text { STATEGROWT H }_{i} \\
& +\beta_{10} \text { MSASHARE }_{i}+\varepsilon_{i}
\end{aligned}
$$

The unit of observation used in this analysis is the bank; however, many of our righthand-side variables reflect market or state level conditions. For banks that operate in more than one local market, the value of each market level variable is the depositweighted average of the market level measure for all of the markets from which the bank derives its deposits. For example, if bank $i$ derives $75 \%$ of its deposits from market A and $25 \%$ of its deposits from market $\mathrm{B}$, the value of $M K T C O N C_{i}$ would be equal to $0.75\left(M_{K T C O N C_{A}}\right)+0.25\left(M_{K T C O N C_{B}}\right)$. Similarly, for banks whose operations cross state lines, the value of each state level variable is equal to the deposit-weighted average of the state level measures for each state from which the bank derives its deposits. ${ }^{10}$

Market concentration $\left(M K T C O N C_{i}\right)$ and state concentration $\left(S T A T E C O N C_{i}\right)$ are each measured two different ways -- using the Herfindahl-Hirschmann Index (HHI) and the three firm concentration ratio (CR3). ${ }^{11}$ Control variables include bank size, as measured by the natural logarithm of bank assets, market size and state size, as measured by the natural logarithm of population, per capita income for the market and the state, the rate of growth in deposits over the preceding year for the market and the state, and a variable indicating the share of the bank's deposits derived from urban markets.

The results of estimating equation (2) are summarized in Tables 8 through 10 . Given the large number of equations estimated (three types of accounts, four different years, full and restricted samples, and two alternative concentration measures) we economize on tables by presenting only the results of greatest interest in the context of

\footnotetext{
${ }^{10}$ As a robustness check, we re-ran our analysis on a sub-sample of banks that derive at least 80 percent of their deposits from a single local market. The results were not substantively different from those reported in Tables 8-10.

${ }^{11}$ Concentration measures are based on deposits held at commercial banks. Alternative measures that include thrift deposits with either $50 \%$ or $100 \%$ weight yield similar results to those reported below.
} 
this paper. ${ }^{12}$ Each table presents key results for a particular type of deposit account for all four years. The top panel of each table presents full sample results using the HHI as the concentration measure; the second panel presents results for the full sample using the CR3 concentration measure; the third and fourth panels present results for the urban subsample, using the two alternative concentration measures.

Looking first at NOW accounts, we see that the estimated coefficient on local market concentration is negative and statistically significant at either the $0.10,0.05$ or 0.01 level in every year, regardless of which concentration measure is employed, for both the full sample and the urban subsample. The magnitude of the estimated coefficient varies from year to year, but there is no evidence of a systematic decline over time. Interestingly, the estimated coefficient on state level concentration is also negative in 15 out of 16 cases, and significantly different from zero at the 0.01 level in every specification for 1992, 1996 and 1999. The magnitude of the estimated coefficient on state concentration appears to be increasing over time, suggesting that state level concentration may have become a more important factor influencing the deposit interest rates offered on NOW accounts over the 1988 to 1999 time period.

Looking next at MMDA accounts, we find that the estimated coefficient on the local concentration variable is negative in every case, and significantly different from zero at the 0.05 or 0.01 level in ten cases. Again, there is no evidence of a systematic decline over time in the magnitude of the estimated coefficient. On the contrary, for each sample and each concentration measure, the estimated coefficient on local concentration is greater in absolute value for 1999 than for any of the other years. The estimated coefficient on state concentration is negative in 13 out of 16 cases and significantly different from zero at the 0.05 or 0.01 level in seven of these cases, including three of the four specifications in 1996 and all four specifications in 1999. For reasons that are not obvious, we get a positive, statistically significant coefficient estimate for this variable in the full sample specification using CR3 as the concentration measure for 1992. Again, it appears that state level concentration has an increasingly strong relationship with deposit interest rates in the late 1990s.

\footnotetext{
${ }^{12}$ Complete regression results are available from the authors upon request.
} 
Finally, looking at the savings account results we find that the estimated coefficient on local market concentration is negative in every case, and significantly different from zero at the five or one percent level in 13 out of 16 cases. While there is no obvious pattern over time in the magnitudes of the estimated coefficients on local market concentration for the full sample runs, when we restrict our analysis to the urban subsample, the importance of local market concentration as a determinant of deposit interest rates appears to be increasing over time. Interestingly, the relationship between deposit interest rates and state level concentration is less evident for savings accounts than for NOW and MMDA accounts. Estimated coefficients on the state concentration variable are negative in 11 out of 16 cases, and significantly different from zero at the $0.10,0.05$ or 0.01 level in seven instances. There is no evidence of increasing strength of this relationship over time.

Overall, these findings do not support the view that the concept of local banking markets has become obsolete. For the three account types examined, there is no evidence of a diminishing of the relationship between local market concentration and price over time. We also find that the negative relationship between state level concentration and deposit interest rates identified by Radecki in his examination of 1996 data is not new, but existed at least as early as 1992. The underlying cause of this relationship and its implications for antitrust policy are unclear and warrant further investigation.

\section{Conclusion}

Our analyses of within-state differences in interest rates paid on retail deposit accounts in 1988, 1992, 1996, and 1999 generally reject the hypothesis of statewide (as opposed to local) geographic markets for NOW accounts in all years and for MMDA accounts in all years except 1999. We cannot generally reject the hypothesis of statewide markets for savings accounts, except in 1992. Thus, while there is strong evidence that markets for NOW accounts did not grow larger during the 1990s, our results can neither confirm nor reject the hypothesis of a broadening of the geographic scope of markets for MMDA and savings accounts.

Our analysis of the effects of concentration measures on interest rates reveals that local concentration measures are negatively related to rates paid on NOW accounts 
in all years, regardless of whether all markets or only urban markets are examined and whether the Herfindahl index or the three-firm concentration ratio is used. In the case of savings accounts, we also find a negative relationship between local concentration and the deposit interest rate in fourteen out of sixteen cases. The results for MMDA accounts are somewhat weaker, but we still find evidence of a significant negative relationship in at least one of the four cases considered in each year, and in all four cases for 1999. Our results support the view that local market concentration is an important factor influencing bank pricing behavior.

We also find strong evidence that state-level concentration is negatively related to deposit interest rates offered on NOW and MMDA accounts in recent years. This is true even in those cases where we find strong empirical evidence that markets are local. This suggests that the structure-conduct-performance paradigm in which market concentration alone drives pricing power may be too simplistic. Statewide concentration measures capture the extent to which state banking industries are dominated by large, geographically diversified banks. Hannan and Prager (2001) present evidence suggesting that such banks may compete less aggressively for retail deposits than smaller locally based institutions. Larger banks may have better access to wholesale funds markets, obviating the need to price aggressively in order to attract retail deposits. Alternatively, tacit collusion may be more effective for banks that compete with one-another in many local markets. Our analysis suggests that while local market concentration measures are useful predictors of bank pricing power, broader concentration measures may also provide useful information for analyzing the competitive impact of proposed bank mergers. 


\section{References}

Amel, Dean F. and Martha Starr-Mccluer. "Market Definition in Banking: Recent Evidence," Antitrust Bulletin (Forthcoming, 2002).

Berger, Allen N. and Timothy H. Hannan. "The Price Concentration Relationship in Banking," Review of Economics and Statistics 71 (1989) pp. 291-299.

Calem, Paul S. and Gerald A. Carlino. "The Concentration/Conduct Relationship in Bank Deposit Markets," Review of Economics and Statistics 73 (1991) pp. 268-76.

Hannan, Timothy H. "Market Share Inequality, the Number of Competitors, and the HHI," Review of Industrial Organization 12 (1997) pp. 23-35.

Hannan, Timothy H. and Robin A. Prager. "The Competitive Implications of Multimarket Bank Branching,” Finance and Economics Discussion Series \#2001-43. Federal Reserve Board (2001).

Heitfield, E.A. "What Do Interest Rate Data Say About the Geography of Retail Banking Markets?” Antitrust Bulletin 44 (1999) pp. 333-347.

Kwast, M.L., Starr-McCluer, M. and Wolken, J.D. "Market Definition and the Analysis of Antitrust in Banking," Antitrust Bulletin 42 (1997) pp. 973-995.

Pilloff, Steven J. and Stephen A. Rhoades. "Structure and Profitability in Banking Markets," Review of Industrial Organization 20 (2002) pp. 81-98.

Prager, Robin A. and Timothy H. Hannan. "Do Substantial Horizontal Mergers Generate Significant Price Effects? Evidence from the Banking Industry," The Journal of Industrial Economics 46 (1998) pp. 433-452. 
Radecki, Lawrence J. "The Expanding Geographic Reach of Retail Banking Markets," Federal Reserve Bank of New York Economic Policy Review (June 1998) pp. 15-33. 
Table 1

Summary Statistics for Deposit Interest Rates (\% per year)

\begin{tabular}{|l|c|c|c|c|c|}
\hline & $\begin{array}{c}\text { Number of } \\
\text { Obs. }\end{array}$ & Mean & Std. Dev. & Min. & Max. \\
\hline 1988 & & & & & \\
NOW & 11,756 & 5.104 & 0.513 & 3.389 & 7.185 \\
MMDA & 11,338 & 5.694 & 0.507 & 4.411 & 7.837 \\
SAVINGS & 11,250 & 5.353 & 0.604 & 3.806 & 9.325 \\
1992 & & & & & \\
NOW & 10,524 & 3.235 & 0.527 & 1.872 & 4.755 \\
MMDA & 10,070 & 3.645 & 0.422 & 2.551 & 5.071 \\
SAVINGS & 10,181 & 3.702 & 0.539 & 2.457 & 5.811 \\
1996 & & & & & \\
NOW & 8,497 & 2.403 & 0.610 & 0.988 & 4.699 \\
MMDA & 8,154 & 3.332 & 0.639 & 1.946 & 5.140 \\
SAVINGS & 8,430 & 2.919 & 0.607 & 1.737 & 5.163 \\
1999 & & & & & \\
NOW & 7,449 & 2.212 & 0.721 & 0.617 & 4.602 \\
MMDA & 7,276 & 3.370 & 0.717 & 1.562 & 5.042 \\
SAVINGS & 7,485 & 2.687 & 0.675 & 1.126 & 4.894 \\
\hline
\end{tabular}


Table 2: NOW Accounts - All Markets

\begin{tabular}{|c|c|c|c|c|c|c|c|c|c|}
\hline State & Year & $\begin{array}{l}\text { Number } \\
\text { of Banks }\end{array}$ & $\begin{array}{c}\text { Number } \\
\text { of Markets }\end{array}$ & $\begin{array}{l}\text { F-Test } \\
\text { Statistic }\end{array}$ & $\begin{array}{c}\text { F-Test } \\
\text { P-Value }\end{array}$ & Mark & $\begin{array}{c}50 \text { th } \\
\text { (median) }\end{array}$ & 75th & $\begin{array}{l}\text { Inter- } \\
\text { quartile } \\
\text { Range }\end{array}$ \\
\hline CA & 88 & 371 & 40 & 0.81 & 0.7923 & 2.98 & 3.20 & 3.50 & 0.52 \\
\hline CA & 92 & 361 & 41 & 1.63 & 0.0127 & 2.46 & 2.68 & 3.04 & 0.58 \\
\hline CA & 96 & 264 & 41 & 1.50 & 0.0358 & 1.16 & 1.47 & 1.77 & 0.61 \\
\hline CA & 99 & 224 & 44 & 1.10 & 0.3203 & 0.84 & 1.15 & 1.67 & 0.83 \\
\hline FL & 88 & 311 & 52 & 1.04 & 0.4125 & 4.96 & 5.13 & 5.30 & 0.34 \\
\hline FL & 92 & 333 & 53 & 2.79 & $<.0001$ & 3.73 & 3.87 & 4.12 & 0.40 \\
\hline FL & 96 & 242 & 49 & 2.18 & 0.0001 & 2.20 & 2.42 & 2.76 & 0.56 \\
\hline FL & 99 & 190 & 45 & 1.63 & 0.0176 & 2.22 & 2.66 & 3.16 & 0.93 \\
\hline GA & 88 & 315 & 124 & 0.70 & 0.9821 & 6.01 & 6.26 & 6.48 & 0.48 \\
\hline GA & 92 & 367 & 120 & 1.68 & 0.0004 & 3.82 & 4.08 & 4.41 & 0.59 \\
\hline GA & 96 & 314 & 114 & 2.18 & $<.0001$ & 2.59 & 2.98 & 3.30 & 0.71 \\
\hline GA & 99 & 297 & 114 & 1.75 & 0.0004 & 1.71 & 2.17 & 2.62 & 0.91 \\
\hline IL & 88 & 1050 & 88 & 1.52 & 0.0021 & 5.35 & 5.47 & 5.59 & 0.24 \\
\hline $\mathrm{IL}$ & 92 & 897 & 88 & 3.43 & $<.0001$ & 4.15 & 4.31 & 4.52 & 0.37 \\
\hline $\mathrm{IL}$ & 96 & 727 & 83 & 2.05 & $<.0001$ & 2.92 & 3.14 & 3.34 & 0.42 \\
\hline IL & 99 & 631 & 83 & 1.57 & 0.0019 & 2.72 & 2.95 & 3.15 & 0.44 \\
\hline MI & 88 & 271 & 72 & 1.38 & 0.0447 & 5.16 & 5.35 & 5.54 & 0.38 \\
\hline MI & 92 & 204 & 66 & 1.26 & 0.1313 & 2.33 & 2.68 & 2.94 & 0.61 \\
\hline MI & 96 & 161 & 55 & 1.03 & 0.4423 & 0.41 & 0.81 & 1.31 & 0.90 \\
\hline MI & 99 & 147 & 52 & 1.13 & 0.2956 & -0.14 & 0.21 & 1.00 & 1.14 \\
\hline NJ & 88 & 66 & 8 & 0.84 & 0.5608 & 5.39 & 5.52 & 5.67 & 0.28 \\
\hline NJ & 92 & 71 & 8 & 0.84 & 0.5571 & 3.13 & 3.32 & 3.45 & 0.32 \\
\hline $\mathrm{NJ}$ & 96 & 45 & 8 & 1.85 & 0.1097 & 2.21 & 2.49 & 2.75 & 0.54 \\
\hline $\mathrm{NJ}$ & 99 & 44 & 8 & 1.53 & 0.1905 & 0.77 & 1.39 & 1.61 & 0.84 \\
\hline NY & 88 & 123 & 40 & 0.76 & 0.8227 & 4.80 & 5.06 & 5.27 & 0.46 \\
\hline NY & 92 & 119 & 40 & 1.62 & 0.036 & 3.73 & 4.09 & 4.46 & 0.73 \\
\hline NY & 96 & 104 & 37 & 1.34 & 0.1545 & 1.39 & 1.74 & 2.11 & 0.72 \\
\hline NY & 99 & 93 & 30 & 0.98 & 0.5084 & -0.38 & 0.15 & 0.47 & 0.85 \\
\hline $\mathrm{OH}$ & 88 & 275 & 65 & 1.47 & 0.0237 & 5.06 & 5.29 & 5.53 & 0.47 \\
\hline $\mathrm{OH}$ & 92 & 251 & 65 & 1.61 & 0.0073 & 4.45 & 4.64 & 4.88 & 0.42 \\
\hline $\mathrm{OH}$ & 96 & 224 & 60 & 1.09 & 0.3362 & 3.56 & 3.75 & 4.02 & 0.46 \\
\hline $\mathrm{OH}$ & 99 & 191 & 59 & 1.53 & 0.025 & 2.71 & 3.03 & 3.35 & 0.64 \\
\hline PA & 88 & 265 & 49 & 2.14 & 0.0001 & 5.78 & 6.15 & 6.31 & 0.53 \\
\hline PA & 92 & 274 & 49 & 2.15 & 0.0001 & 4.64 & 4.94 & 5.30 & 0.66 \\
\hline PA & 96 & 208 & 47 & 1.38 & 0.0776 & 3.39 & 3.77 & 4.11 & 0.72 \\
\hline PA & 99 & 171 & 47 & 0.94 & 0.5803 & 2.41 & 2.86 & 3.26 & 0.85 \\
\hline $\mathrm{TX}$ & 88 & 1379 & 218 & 1.49 & $<.0001$ & 5.41 & 5.60 & 5.76 & 0.35 \\
\hline TX & 92 & 1015 & 220 & 1.81 & $<.0001$ & 3.69 & 3.87 & 4.10 & 0.41 \\
\hline $\mathrm{TX}$ & 96 & 826 & 212 & 1.95 & $<.0001$ & 2.51 & 2.81 & 3.12 & 0.61 \\
\hline $\mathrm{TX}$ & 99 & 683 & 208 & 1.33 & 0.0067 & 2.12 & 2.44 & 2.79 & 0.67 \\
\hline
\end{tabular}


Table 3: NOW Accounts - Urban Markets

\begin{tabular}{|c|c|c|c|c|c|c|c|c|c|}
\hline State & Year & $\begin{array}{l}\text { Number } \\
\text { of Banks }\end{array}$ & $\begin{array}{c}\text { Number } \\
\text { of Markets }\end{array}$ & $\begin{array}{l}\text { F-Test } \\
\text { Statistic }\end{array}$ & $\begin{array}{c}\text { F-Test } \\
\text { P-Value }\end{array}$ & Mark & $\begin{array}{c}50 \text { th } \\
\text { (median) }\end{array}$ & 75th & $\begin{array}{l}\text { Inter- } \\
\text { quartile } \\
\text { Range }\end{array}$ \\
\hline CA & 88 & 342 & 23 & 1.22 & 0.2298 & 5.68 & 5.80 & 5.94 & 0.26 \\
\hline CA & 92 & 327 & 23 & 2.24 & 0.0014 & 3.35 & 3.62 & 3.77 & 0.42 \\
\hline CA & 96 & 242 & 25 & 1.99 & 0.0054 & 1.89 & 2.18 & 2.50 & 0.61 \\
\hline CA & 99 & 202 & 25 & 1.23 & 0.2239 & 0.84 & 1.04 & 1.35 & 0.50 \\
\hline FL & 88 & 248 & 20 & 1.51 & 0.0843 & 5.60 & 5.69 & 5.77 & 0.17 \\
\hline FL & 92 & 265 & 20 & 3.11 & $<.0001$ & 3.68 & 3.74 & 3.98 & 0.30 \\
\hline FL & 96 & 194 & 20 & 2.29 & 0.0027 & 2.05 & 2.17 & 2.35 & 0.31 \\
\hline FL & 99 & 150 & 20 & 2.02 & 0.0113 & 2.42 & 2.75 & 3.02 & 0.61 \\
\hline GA & 88 & 92 & 7 & 1.89 & 0.092 & 5.96 & 6.47 & 6.56 & 0.59 \\
\hline GA & 92 & 126 & 7 & 0.52 & 0.789 & 3.30 & 3.44 & 3.51 & 0.21 \\
\hline GA & 96 & 96 & 7 & 1.49 & 0.1896 & 2.73 & 2.78 & 3.27 & 0.53 \\
\hline GA & 99 & 91 & 7 & 1.44 & 0.2114 & 2.40 & 2.61 & 2.92 & 0.52 \\
\hline IL & 88 & 557 & 12 & 3.15 & 0.0004 & 5.34 & 5.50 & 5.60 & 0.27 \\
\hline $\mathrm{IL}$ & 92 & 459 & 12 & 3.98 & $<.0001$ & 4.03 & 4.17 & 4.30 & 0.27 \\
\hline $\mathrm{IL}$ & 96 & 359 & 9 & 4.77 & $<.0001$ & 2.78 & 2.91 & 3.01 & 0.23 \\
\hline IL & 99 & 296 & 9 & 3.62 & 0.0005 & 2.46 & 2.87 & 3.00 & 0.54 \\
\hline MI & 88 & 119 & 11 & 1.30 & 0.2383 & 4.63 & 4.75 & 4.81 & 0.18 \\
\hline MI & 92 & 81 & 11 & 0.56 & 0.8378 & 3.47 & 3.67 & 3.71 & 0.24 \\
\hline MI & 96 & 69 & 9 & 0.35 & 0.9433 & 1.84 & 2.00 & 2.06 & 0.22 \\
\hline MI & 99 & 64 & 9 & 1.81 & 0.096 & 2.17 & 2.37 & 2.67 & 0.50 \\
\hline NJ & 88 & 66 & 8 & 0.84 & 0.5608 & 5.39 & 5.52 & 5.67 & 0.28 \\
\hline NJ & 92 & 71 & 8 & 0.84 & 0.5571 & 3.13 & 3.32 & 3.45 & 0.32 \\
\hline $\mathrm{NJ}$ & 96 & 45 & 8 & 1.85 & 0.1097 & 2.21 & 2.49 & 2.75 & 0.54 \\
\hline $\mathrm{NJ}$ & 99 & 44 & 8 & 1.53 & 0.1905 & 0.77 & 1.39 & 1.61 & 0.84 \\
\hline NY & 88 & 76 & 13 & 0.55 & 0.8742 & 4.43 & 4.49 & 4.59 & 0.16 \\
\hline NY & 92 & 80 & 13 & 3.00 & 0.0022 & 3.53 & 3.68 & 3.88 & 0.35 \\
\hline NY & 96 & 71 & 13 & 1.49 & 0.1559 & 1.37 & 1.57 & 1.93 & 0.56 \\
\hline NY & 99 & 61 & 11 & 1.08 & 0.3943 & 0.02 & 0.72 & 0.85 & 0.84 \\
\hline $\mathrm{OH}$ & 88 & 121 & 13 & 1.63 & 0.0938 & 4.11 & 4.38 & 4.50 & 0.38 \\
\hline $\mathrm{OH}$ & 92 & 106 & 13 & 2.66 & 0.0042 & 3.82 & 3.98 & 4.04 & 0.22 \\
\hline $\mathrm{OH}$ & 96 & 94 & 12 & 0.92 & 0.5269 & 3.97 & 4.18 & 4.40 & 0.43 \\
\hline $\mathrm{OH}$ & 99 & 80 & 12 & 1.61 & 0.1181 & 2.79 & 2.99 & 3.17 & 0.38 \\
\hline PA & 88 & 170 & 15 & 2.35 & 0.0056 & 5.35 & 5.67 & 5.80 & 0.45 \\
\hline PA & 92 & 182 & 15 & 3.18 & 0.0002 & 4.27 & 4.38 & 4.78 & 0.51 \\
\hline PA & 96 & 133 & 14 & 1.72 & 0.0659 & 2.83 & 2.97 & 3.21 & 0.37 \\
\hline PA & 99 & 106 & 14 & 1.52 & 0.125 & 2.21 & 2.66 & 2.81 & 0.60 \\
\hline $\mathrm{TX}$ & 88 & 779 & 28 & 2.73 & $<.0001$ & 5.42 & 5.50 & 5.65 & 0.23 \\
\hline TX & 92 & 497 & 28 & 2.45 & $<.0001$ & 3.49 & 3.67 & 3.84 & 0.35 \\
\hline $\mathrm{TX}$ & 96 & 387 & 27 & 2.89 & $<.0001$ & 2.68 & 2.95 & 3.25 & 0.58 \\
\hline $\mathrm{TX}$ & 99 & 300 & 27 & 1.97 & 0.0043 & 2.63 & 2.93 & 3.14 & 0.51 \\
\hline
\end{tabular}


Table 4: Money Market Deposit Accounts - All Markets

\begin{tabular}{|c|c|c|c|c|c|c|c|c|c|}
\hline State & Year & $\begin{array}{l}\text { Number } \\
\text { of Banks }\end{array}$ & $\begin{array}{c}\text { Number } \\
\text { of Markets }\end{array}$ & $\begin{array}{l}\text { F-Test } \\
\text { Statistic }\end{array}$ & $\begin{array}{c}\text { F-Test } \\
\text { P-Value }\end{array}$ & $25^{\text {th }}$ & $\begin{array}{c}50 \text { th } \\
\text { (median) }\end{array}$ & 75th & $\begin{array}{l}\text { Inter- } \\
\text { quartile } \\
\text { Range }\end{array}$ \\
\hline CA & 88 & 376 & 37 & 1.19 & 0.217 & 2.59 & 2.79 & 2.95 & 0.36 \\
\hline CA & 92 & 372 & 41 & 1.26 & 0.1432 & 2.89 & 3.04 & 3.27 & 0.38 \\
\hline CA & 96 & 282 & 41 & 1.07 & 0.364 & 1.35 & 1.66 & 2.00 & 0.65 \\
\hline $\mathrm{CA}$ & 99 & 242 & 44 & 1.55 & 0.0239 & 2.02 & 2.53 & 2.91 & 0.90 \\
\hline FL & 88 & 317 & 52 & 1.27 & 0.1174 & 5.00 & 5.14 & 5.36 & 0.36 \\
\hline FL & 92 & 358 & 55 & 1.68 & 0.0038 & 3.77 & 3.88 & 4.08 & 0.31 \\
\hline FL & 96 & 249 & 51 & 2.09 & 0.0002 & 3.43 & 3.81 & 4.31 & 0.88 \\
\hline FL & 99 & 205 & 45 & 1.26 & 0.155 & 2.40 & 2.84 & 3.37 & 0.97 \\
\hline GA & 88 & 315 & 124 & 1.55 & 0.0036 & 5.85 & 6.02 & 6.25 & 0.41 \\
\hline GA & 92 & 367 & 121 & 2.19 & $<.0001$ & 3.93 & 4.18 & 4.44 & 0.51 \\
\hline GA & 96 & 311 & 113 & 1.56 & 0.0035 & 2.97 & 3.20 & 3.48 & 0.52 \\
\hline GA & 99 & 288 & 113 & 1.09 & 0.3052 & 2.18 & 2.67 & 3.02 & 0.85 \\
\hline IL & 88 & 974 & 88 & 2.09 & $<.0001$ & 5.69 & 5.81 & 6.03 & 0.33 \\
\hline IL & 92 & 850 & 88 & 2.82 & $<.0001$ & 4.03 & 4.21 & 4.38 & 0.35 \\
\hline IL & 96 & 672 & 80 & 1.73 & 0.0002 & 2.31 & 2.53 & 2.80 & 0.50 \\
\hline $\mathrm{IL}$ & 99 & 605 & 79 & 1.22 & 0.1094 & 3.03 & 3.29 & 3.53 & 0.50 \\
\hline MI & 88 & 268 & 71 & 1.49 & 0.0181 & 5.50 & 5.66 & 5.92 & 0.42 \\
\hline MI & 92 & 205 & 66 & 0.92 & 0.6443 & 2.59 & 2.75 & 3.01 & 0.42 \\
\hline MI & 96 & 154 & 53 & 1.28 & 0.1454 & 0.28 & 0.76 & 1.23 & 0.96 \\
\hline MI & 99 & 147 & 50 & 0.94 & 0.5946 & 0.05 & 0.61 & 1.13 & 1.08 \\
\hline $\mathrm{NJ}$ & 88 & 72 & 8 & 2.03 & 0.0651 & 5.08 & 5.25 & 5.57 & 0.49 \\
\hline NJ & 92 & 69 & 8 & 3.12 & 0.0073 & 2.92 & 3.16 & 3.54 & 0.62 \\
\hline $\mathrm{NJ}$ & 96 & 48 & 8 & 1.02 & 0.4357 & 0.18 & 0.41 & 0.88 & 0.71 \\
\hline $\mathrm{NJ}$ & 99 & 44 & 8 & 1.86 & 0.1088 & 6.52 & 6.77 & 7.05 & 0.53 \\
\hline NY & 88 & 128 & 40 & 0.83 & 0.7359 & 4.81 & 5.02 & 5.14 & 0.33 \\
\hline NY & 92 & 119 & 40 & 1.93 & 0.0072 & 3.01 & 3.45 & 3.72 & 0.71 \\
\hline NY & 96 & 106 & 37 & 1.59 & 0.0512 & 2.12 & 2.86 & 3.37 & 1.25 \\
\hline $\mathrm{NY}$ & 99 & 98 & 33 & 0.99 & 0.4938 & 2.97 & 3.39 & 3.89 & 0.92 \\
\hline $\mathrm{OH}$ & 88 & 261 & 65 & 1.18 & 0.1986 & 5.28 & 5.48 & 5.68 & 0.40 \\
\hline $\mathrm{OH}$ & 92 & 236 & 65 & 1.90 & 0.0006 & 4.56 & 4.81 & 5.00 & 0.45 \\
\hline $\mathrm{OH}$ & 96 & 209 & 61 & 0.74 & 0.9083 & 2.80 & 3.09 & 3.47 & 0.67 \\
\hline $\mathrm{OH}$ & 99 & 175 & 59 & 0.77 & 0.8648 & 2.97 & 3.26 & 3.60 & 0.63 \\
\hline PA & 88 & 271 & 49 & 2.78 & $<.0001$ & 5.65 & 5.92 & 6.11 & 0.46 \\
\hline PA & 92 & 265 & 49 & 3.11 & $<.0001$ & 4.64 & 4.93 & 5.16 & 0.52 \\
\hline PA & 96 & 207 & 48 & 1.53 & 0.0276 & 3.41 & 3.87 & 4.27 & 0.86 \\
\hline PA & 99 & 172 & 47 & 1.91 & 0.0027 & 4.17 & 4.73 & 5.61 & 1.44 \\
\hline $\mathrm{TX}$ & 88 & 1378 & 221 & 2.15 & $<.0001$ & 5.63 & 5.81 & 6.08 & 0.46 \\
\hline $\mathrm{TX}$ & 92 & 988 & 222 & 1.47 & $<.0001$ & 3.47 & 3.65 & 3.81 & 0.34 \\
\hline $\mathrm{TX}$ & 96 & 807 & 211 & 1.38 & 0.0017 & 2.11 & 2.37 & 2.61 & 0.50 \\
\hline TX & 99 & 683 & 206 & 1.17 & 0.0891 & 1.96 & 2.27 & 2.59 & 0.63 \\
\hline
\end{tabular}


Table 5: Money Market Deposit Accounts - Urban Markets

\begin{tabular}{|c|c|c|c|c|c|c|c|c|c|}
\hline State & Year & $\begin{array}{l}\text { Number } \\
\text { of Banks }\end{array}$ & $\begin{array}{c}\text { Number } \\
\text { of Markets }\end{array}$ & $\begin{array}{l}\text { F-Test } \\
\text { Statistic }\end{array}$ & $\begin{array}{c}\text { F-Test } \\
\text { P-Value }\end{array}$ & Mark & $\begin{array}{c}50 \text { th } \\
\text { (median) }\end{array}$ & entile & $\begin{array}{l}\text { Inter- } \\
\text { quartile } \\
\text { Range }\end{array}$ \\
\hline CA & 88 & 348 & 23 & 2.54 & 0.0002 & 5.37 & 5.53 & 5.72 & 0.34 \\
\hline CA & 92 & 337 & 23 & 1.27 & 0.1926 & 3.73 & 3.81 & 3.92 & 0.19 \\
\hline CA & 96 & 257 & 25 & 1.38 & 0.1183 & 2.19 & 2.35 & 2.53 & 0.34 \\
\hline $\mathrm{CA}$ & 99 & 218 & 25 & 1.39 & 0.1143 & 2.12 & 2.43 & 2.59 & 0.47 \\
\hline FL & 88 & 253 & 20 & 2.90 & $<.0001$ & 5.53 & 5.62 & 5.67 & 0.14 \\
\hline FL & 92 & 285 & 20 & 2.70 & 0.0002 & 3.61 & 3.69 & 3.80 & 0.19 \\
\hline FL & 96 & 200 & 20 & 2.68 & 0.0004 & 3.39 & 3.61 & 3.93 & 0.54 \\
\hline FL & 99 & 163 & 20 & 1.54 & 0.0804 & 3.68 & 3.92 & 4.44 & 0.76 \\
\hline GA & 88 & 97 & 7 & 0.57 & 0.7557 & 5.42 & 5.64 & 5.66 & 0.24 \\
\hline GA & 92 & 127 & 7 & 0.60 & 0.7302 & 3.67 & 3.68 & 3.85 & 0.18 \\
\hline GA & 96 & 101 & 7 & 0.97 & 0.4503 & 2.96 & 3.09 & 3.14 & 0.18 \\
\hline GA & 99 & 92 & 7 & 1.21 & 0.3088 & 3.39 & 3.43 & 3.76 & 0.37 \\
\hline IL & 88 & 539 & 12 & 3.27 & 0.0002 & 5.70 & 5.76 & 5.88 & 0.17 \\
\hline IL & 92 & 455 & 12 & 3.74 & $<.0001$ & 4.02 & 4.13 & 4.26 & 0.24 \\
\hline IL & 96 & 351 & 9 & 2.25 & 0.0235 & 2.19 & 2.45 & 2.60 & 0.41 \\
\hline IL & 99 & 309 & 9 & 0.92 & 0.4975 & 3.71 & 4.02 & 4.08 & 0.38 \\
\hline MI & 88 & 118 & 11 & 0.75 & 0.6777 & 5.16 & 5.27 & 5.39 & 0.24 \\
\hline MI & 92 & 83 & 11 & 0.60 & 0.8077 & 3.64 & 3.72 & 3.81 & 0.16 \\
\hline MI & 96 & 70 & 9 & 1.53 & 0.1652 & 3.04 & 3.21 & 3.65 & 0.61 \\
\hline MI & 99 & 68 & 9 & 1.91 & 0.077 & 2.84 & 3.89 & 4.22 & 1.38 \\
\hline NJ & 88 & 72 & 8 & 2.03 & 0.0651 & 5.08 & 5.25 & 5.57 & 0.49 \\
\hline NJ & 92 & 69 & 8 & 3.12 & 0.0073 & 2.92 & 3.16 & 3.54 & 0.62 \\
\hline NJ & 96 & 48 & 8 & 1.02 & 0.4357 & 0.18 & 0.41 & 0.88 & 0.71 \\
\hline NJ & 99 & 44 & 8 & 1.86 & 0.1088 & 6.52 & 6.77 & 7.05 & 0.53 \\
\hline NY & 88 & 83 & 13 & 0.39 & 0.9641 & 4.27 & 4.42 & 4.53 & 0.27 \\
\hline NY & 92 & 84 & 13 & 3.40 & 0.0006 & 3.08 & 3.40 & 3.58 & 0.50 \\
\hline NY & 96 & 73 & 13 & 1.93 & 0.049 & 2.55 & 2.93 & 3.17 & 0.62 \\
\hline NY & 99 & 68 & 13 & 1.04 & 0.4281 & 2.75 & 3.21 & 3.44 & 0.70 \\
\hline $\mathrm{OH}$ & 88 & 118 & 13 & 1.95 & 0.0372 & 4.67 & 5.00 & 5.20 & 0.53 \\
\hline $\mathrm{OH}$ & 92 & 106 & 13 & 2.12 & 0.0232 & 3.81 & 3.94 & 4.17 & 0.36 \\
\hline $\mathrm{OH}$ & 96 & 97 & 12 & 0.61 & 0.8115 & 2.72 & 2.87 & 3.11 & 0.38 \\
\hline $\mathrm{OH}$ & 99 & 80 & 12 & 1.44 & 0.178 & 3.16 & 3.31 & 3.53 & 0.38 \\
\hline PA & 88 & 171 & 15 & 1.98 & 0.0227 & 5.12 & 5.35 & 5.53 & 0.40 \\
\hline PA & 92 & 173 & 15 & 3.29 & 0.0001 & 4.37 & 4.50 & 4.65 & 0.28 \\
\hline PA & 96 & 134 & 14 & 0.83 & 0.6274 & 3.08 & 3.22 & 3.31 & 0.23 \\
\hline PA & 99 & 106 & 14 & 1.77 & 0.0613 & 3.90 & 4.21 & 4.35 & 0.45 \\
\hline $\mathrm{TX}$ & 88 & 787 & 28 & 4.04 & $<.0001$ & 5.47 & 5.73 & 5.84 & 0.37 \\
\hline TX & 92 & 492 & 28 & 1.52 & 0.0483 & 3.45 & 3.60 & 3.69 & 0.24 \\
\hline TX & 96 & 387 & 27 & 1.69 & 0.0199 & 2.27 & 2.50 & 2.57 & 0.30 \\
\hline TX & 99 & 309 & 27 & 1.10 & 0.3355 & 3.02 & 3.29 & 3.43 & 0.40 \\
\hline
\end{tabular}


Table 6: Savings Accounts - All Markets

\begin{tabular}{|c|c|c|c|c|c|c|c|c|c|}
\hline State & Year & $\begin{array}{l}\text { Number } \\
\text { of Banks }\end{array}$ & $\begin{array}{c}\text { Number } \\
\text { of Markets }\end{array}$ & $\begin{array}{l}\text { F-Test } \\
\text { Statistic }\end{array}$ & $\begin{array}{c}\text { F-Test } \\
\text { P-Value }\end{array}$ & $25^{\text {th }}$ & $\begin{array}{c}\text { 50th } \\
\text { (median) }\end{array}$ & 75th & $\begin{array}{l}\text { Inter- } \\
\text { quartile } \\
\text { Range } \\
\end{array}$ \\
\hline CA & 88 & 359 & 40 & 0.98 & 0.5127 & 2.94 & 3.18 & 3.38 & 0.44 \\
\hline CA & 92 & 362 & 41 & 1.35 & 0.0831 & 3.18 & 3.37 & 3.76 & 0.58 \\
\hline CA & 96 & 271 & 41 & 1.06 & 0.3771 & 1.97 & 2.18 & 2.49 & 0.52 \\
\hline CA & 99 & 233 & 44 & 0.77 & 0.8464 & 2.36 & 2.73 & 3.11 & 0.76 \\
\hline FL & 88 & 312 & 52 & 1.75 & 0.0027 & 4.91 & 5.07 & 5.26 & 0.35 \\
\hline FL & 92 & 355 & 54 & 1.91 & 0.0004 & 3.97 & 4.16 & 4.44 & 0.48 \\
\hline FL & 96 & 238 & 51 & 0.96 & 0.5567 & 0.49 & 0.68 & 0.99 & 0.50 \\
\hline FL & 99 & 197 & 47 & 0.95 & 0.5695 & 0.78 & 1.13 & 1.67 & 0.89 \\
\hline GA & 88 & 295 & 125 & 0.97 & 0.5726 & 4.80 & 5.06 & 5.23 & 0.43 \\
\hline GA & 92 & 358 & 122 & 1.93 & $<.0001$ & 4.28 & 4.53 & 4.83 & 0.55 \\
\hline GA & 96 & 316 & 116 & 1.15 & 0.1925 & 3.36 & 3.61 & 3.88 & 0.51 \\
\hline GA & 99 & 299 & 115 & 1.14 & 0.2144 & 2.20 & 2.51 & 2.92 & 0.72 \\
\hline IL & 88 & 1022 & 88 & 1.04 & 0.3943 & 5.08 & 5.18 & 5.28 & 0.21 \\
\hline $\mathrm{IL}$ & 92 & 880 & 88 & 1.86 & $<.0001$ & 4.37 & 4.55 & 4.79 & 0.42 \\
\hline $\mathrm{IL}$ & 96 & 734 & 83 & 1.54 & 0.0028 & 3.07 & 3.26 & 3.43 & 0.36 \\
\hline IL & 99 & 644 & 83 & 1.28 & 0.0565 & 3.13 & 3.36 & 3.59 & 0.46 \\
\hline MI & 88 & 270 & 72 & 1.13 & 0.2616 & 5.10 & 5.37 & 5.67 & 0.57 \\
\hline MI & 92 & 206 & 68 & 1.46 & 0.0338 & 3.76 & 3.99 & 4.25 & 0.49 \\
\hline MI & 96 & 162 & 55 & 0.68 & 0.9412 & 0.99 & 1.20 & 1.71 & 0.72 \\
\hline MI & 99 & 149 & 53 & 0.75 & 0.8723 & 0.31 & 0.73 & 1.07 & 0.75 \\
\hline $\mathrm{NJ}$ & 88 & 78 & 8 & 1.10 & 0.372 & 5.40 & 5.78 & 5.97 & 0.57 \\
\hline NJ & 92 & 69 & 8 & 1.66 & 0.1382 & 3.14 & 3.28 & 3.48 & 0.34 \\
\hline $\mathrm{NJ}$ & 96 & 45 & 8 & 3.42 & 0.0071 & 2.71 & 3.09 & 3.49 & 0.78 \\
\hline $\mathrm{NJ}$ & 99 & 47 & 8 & 0.52 & 0.8106 & 3.22 & 3.31 & 3.43 & 0.21 \\
\hline NY & 88 & 139 & 40 & 1.93 & 0.0049 & 4.84 & 5.06 & 5.30 & 0.46 \\
\hline NY & 92 & 124 & 40 & 1.96 & 0.0055 & 4.12 & 4.47 & 4.78 & 0.66 \\
\hline NY & 96 & 112 & 37 & 0.61 & 0.9468 & 1.65 & 1.98 & 2.20 & 0.55 \\
\hline NY & 99 & 108 & 36 & 0.73 & 0.8422 & 2.69 & 2.99 & 3.37 & 0.68 \\
\hline $\mathrm{OH}$ & 88 & 277 & 65 & 1.01 & 0.4679 & 5.45 & 5.62 & 5.82 & 0.37 \\
\hline $\mathrm{OH}$ & 92 & 250 & 63 & 1.27 & 0.1164 & 4.62 & 4.76 & 5.00 & 0.37 \\
\hline $\mathrm{OH}$ & 96 & 237 & 61 & 0.91 & 0.6503 & 3.54 & 3.74 & 3.98 & 0.44 \\
\hline $\mathrm{OH}$ & 99 & 195 & 59 & 0.86 & 0.7469 & 3.16 & 3.44 & 3.76 & 0.59 \\
\hline PA & 88 & 270 & 49 & 1.20 & 0.1921 & 5.81 & 6.07 & 6.27 & 0.47 \\
\hline PA & 92 & 271 & 49 & 1.96 & 0.0006 & 5.21 & 5.59 & 5.79 & 0.58 \\
\hline PA & 96 & 215 & 48 & 0.86 & 0.7283 & 4.01 & 4.31 & 4.65 & 0.64 \\
\hline PA & 99 & 183 & 46 & 1.17 & 0.2471 & 3.45 & 3.85 & 4.19 & 0.74 \\
\hline $\mathrm{TX}$ & 88 & 1285 & 217 & 1.35 & 0.0015 & 5.30 & 5.50 & 5.73 & 0.43 \\
\hline TX & 92 & 971 & 223 & 1.56 & $<.0001$ & 3.48 & 3.69 & 3.84 & 0.36 \\
\hline $\mathrm{TX}$ & 96 & 813 & 211 & 1.41 & 0.001 & 2.31 & 2.52 & 2.78 & 0.47 \\
\hline $\mathrm{TX}$ & 99 & 673 & 210 & 1.21 & 0.0483 & 2.30 & 2.53 & 2.80 & 0.50 \\
\hline
\end{tabular}


Table 7: Savings Accounts - Urban Markets

\begin{tabular}{|c|c|c|c|c|c|c|c|c|c|}
\hline State & Year & $\begin{array}{l}\text { Number } \\
\text { of Banks }\end{array}$ & $\begin{array}{c}\text { Number } \\
\text { of Markets }\end{array}$ & $\begin{array}{l}\text { F-Test } \\
\text { Statistic }\end{array}$ & $\begin{array}{c}\text { F-Test } \\
\text { P-Value }\end{array}$ & Mark & $\begin{array}{c}50 \text { th } \\
\text { (median) }\end{array}$ & 75th & $\begin{array}{l}\text { Inter- } \\
\text { quartile } \\
\text { Range }\end{array}$ \\
\hline $\mathrm{CA}$ & 88 & 329 & 23 & 2.09 & 0.0033 & 5.35 & 5.55 & 5.72 & 0.37 \\
\hline CA & 92 & 328 & 23 & 1.48 & 0.0801 & 4.17 & 4.35 & 4.56 & 0.38 \\
\hline CA & 96 & 246 & 25 & 1.20 & 0.2478 & 2.63 & 2.77 & 3.02 & 0.39 \\
\hline $\mathrm{CA}$ & 99 & 209 & 25 & 0.72 & 0.8223 & 2.66 & 2.88 & 3.10 & 0.43 \\
\hline FL & 88 & 251 & 20 & 1.85 & 0.0187 & 5.40 & 5.48 & 5.66 & 0.25 \\
\hline FL & 92 & 285 & 20 & 3.23 & $<.0001$ & 3.76 & 3.92 & 4.14 & 0.38 \\
\hline FL & 96 & 190 & 20 & 1.11 & 0.3418 & 0.74 & 0.97 & 1.10 & 0.36 \\
\hline FL & 99 & 158 & 20 & 1.31 & 0.1882 & 1.45 & 1.67 & 2.16 & 0.70 \\
\hline GA & 88 & 86 & 7 & 4.76 & 0.0004 & 4.49 & 4.87 & 4.98 & 0.49 \\
\hline GA & 92 & 119 & 7 & 1.52 & 0.1798 & 4.19 & 4.27 & 4.42 & 0.23 \\
\hline GA & 96 & 98 & 7 & 1.17 & 0.3284 & 3.87 & 4.02 & 4.26 & 0.38 \\
\hline GA & 99 & 92 & 7 & 1.42 & 0.2165 & 3.12 & 3.45 & 3.71 & 0.59 \\
\hline IL & 88 & 543 & 12 & 2.83 & 0.0013 & 4.94 & 4.98 & 5.24 & 0.30 \\
\hline IL & 92 & 448 & 12 & 1.74 & 0.0625 & 4.43 & 4.47 & 4.56 & 0.13 \\
\hline IL & 96 & 363 & 9 & 2.90 & 0.0038 & 2.78 & 2.95 & 2.99 & 0.21 \\
\hline IL & 99 & 313 & 9 & 2.38 & 0.0169 & 2.81 & 2.85 & 3.16 & 0.35 \\
\hline MI & 88 & 117 & 11 & 1.31 & 0.236 & 4.84 & 4.95 & 5.09 & 0.26 \\
\hline MI & 92 & 80 & 11 & 1.25 & 0.279 & 3.49 & 3.63 & 3.84 & 0.35 \\
\hline MI & 96 & 69 & 9 & 0.84 & 0.5722 & 1.69 & 2.09 & 2.20 & 0.51 \\
\hline MI & 99 & 65 & 9 & 1.58 & 0.154 & 2.10 & 2.38 & 2.72 & 0.62 \\
\hline NJ & 88 & 78 & 8 & 1.10 & 0.372 & 5.40 & 5.78 & 5.97 & 0.57 \\
\hline NJ & 92 & 69 & 8 & 1.66 & 0.1382 & 3.14 & 3.28 & 3.48 & 0.34 \\
\hline NJ & 96 & 45 & 8 & 3.42 & 0.0071 & 2.71 & 3.09 & 3.49 & 0.78 \\
\hline NJ & 99 & 47 & 8 & 0.52 & 0.8106 & 3.22 & 3.31 & 3.43 & 0.21 \\
\hline NY & 88 & 88 & 13 & 2.59 & 0.0064 & 4.35 & 4.51 & 4.70 & 0.35 \\
\hline NY & 92 & 83 & 13 & 2.65 & 0.0058 & 3.69 & 3.73 & 3.98 & 0.29 \\
\hline NY & 96 & 74 & 13 & 0.59 & 0.8448 & 1.91 & 2.11 & 2.28 & 0.37 \\
\hline NY & 99 & 69 & 13 & 0.46 & 0.9277 & 3.09 & 3.31 & 3.35 & 0.27 \\
\hline $\mathrm{OH}$ & 88 & 120 & 13 & 1.21 & 0.2845 & 4.86 & 5.02 & 5.21 & 0.35 \\
\hline $\mathrm{OH}$ & 92 & 107 & 13 & 1.02 & 0.4354 & 4.02 & 4.15 & 4.27 & 0.24 \\
\hline $\mathrm{OH}$ & 96 & 105 & 12 & 0.59 & 0.8304 & 3.46 & 3.54 & 3.73 & 0.27 \\
\hline $\mathrm{OH}$ & 99 & 85 & 12 & 0.48 & 0.9101 & 3.17 & 3.38 & 3.50 & 0.33 \\
\hline PA & 88 & 170 & 15 & 1.13 & 0.3397 & 5.48 & 5.59 & 5.79 & 0.31 \\
\hline PA & 92 & 177 & 15 & 2.95 & 0.0005 & 4.70 & 4.93 & 5.11 & 0.41 \\
\hline PA & 96 & 139 & 14 & 0.78 & 0.6784 & 3.27 & 3.53 & 3.86 & 0.58 \\
\hline PA & 99 & 114 & 14 & 1.19 & 0.3019 & 3.88 & 4.02 & 4.34 & 0.46 \\
\hline $\mathrm{TX}$ & 88 & 735 & 28 & 2.57 & $<.0001$ & 5.19 & 5.35 & 5.53 & 0.34 \\
\hline TX & 92 & 470 & 28 & 1.93 & 0.0037 & 3.46 & 3.64 & 3.70 & 0.24 \\
\hline TX & 96 & 387 & 27 & 1.65 & 0.0259 & 2.48 & 2.65 & 2.75 & 0.27 \\
\hline TX & 99 & 301 & 27 & 1.98 & 0.0041 & 2.46 & 2.57 & 2.90 & 0.44 \\
\hline
\end{tabular}


Table 8

Estimated Effects of State and Local Concentration on NOW Account Deposit Interest Rates

\begin{tabular}{l|l|l|l|l}
\hline \multicolumn{1}{c|}{ Sample } & $\begin{array}{c}\text { Concentration } \\
\text { measure }\end{array}$ & Year & $\begin{array}{c}\text { Coefficient on } \\
\text { local } \\
\text { concentration }\end{array}$ & $\begin{array}{c}\text { Coefficient on } \\
\text { state } \\
\text { concentration }\end{array}$ \\
\hline Full & HHI & 1988 & $-0.110^{* * *}$ & -0.145 \\
Full & HHI & 1992 & $-0.215^{* * *}$ & $-1.264^{* * *}$ \\
Full & HHI & 1996 & $-0.092^{*}$ & $-1.872^{* * *}$ \\
Full & HHI & 1999 & $-0.134^{*}$ & $-2.343^{* * *}$ \\
Full & CR3 & 1988 & $-0.143^{* * *}$ & 0.008 \\
Full & CR3 & 1992 & $-0.290^{* * *}$ & $-0.327^{* * *}$ \\
Full & CR3 & 1996 & $-0.139^{* * *}$ & $-0.670^{* * *}$ \\
Full & CR3 & 1999 & $-0.141^{* *}$ & $-0.849^{* * *}$ \\
Urban & HHI & 1988 & $-0.849^{* * *}$ & -0.239 \\
Urban & HHI & 1992 & $-0.475^{* * *}$ & $-1.339^{* * *}$ \\
Urban & HHI & 1996 & $-0.555^{* * *}$ & $-1.843^{* * *}$ \\
Urban & HHI & 1999 & $-0.523^{*}$ & $-1.887^{* * *}$ \\
Urban & CR3 & 1988 & $-0.421^{* * *}$ & -0.095 \\
Urban & CR3 & 1992 & $-0.369^{* * *}$ & $-0.450^{* * *}$ \\
Urban & CR3 & 1996 & $-0.504^{* * *}$ & $-0.683^{* * *}$ \\
Urban & CR3 & 1999 & $-0.250^{*}$ & $-0.813^{* * *}$ \\
\hline
\end{tabular}

$*, * *$, and $* * *$ indicate values that are significantly different from zero at the $0.10,0.05$ and 0.01 levels, respectively. 
Table 9

Estimated Effects of State and Local Concentration on MMDA Deposit Interest Rates

\begin{tabular}{l|l|l|l|l}
\hline \multicolumn{1}{c|}{ Sample } & $\begin{array}{c}\text { Concentration } \\
\text { measure }\end{array}$ & Year & $\begin{array}{c}\text { Coefficient on } \\
\text { local } \\
\text { concentration }\end{array}$ & \multicolumn{1}{|c}{$\begin{array}{c}\text { Coefficient on } \\
\text { state } \\
\text { concentration }\end{array}$} \\
\hline Full & HHI & 1988 & -0.037 & -0.016 \\
Full & HHI & 1992 & $-0.172^{* * *}$ & 0.069 \\
Full & HHI & 1996 & -0.071 & $-0.449^{* *}$ \\
Full & HHI & 1999 & $-0.279^{* * *}$ & $-1.270^{* * *}$ \\
Full & CR3 & 1988 & -0.040 & 0.059 \\
Full & CR3 & 1992 & $-0.211^{* * *}$ & $0.082^{* *}$ \\
Full & CR3 & 1996 & $-0.131^{* *}$ & -0.031 \\
Full & CR3 & 1999 & $-0.438^{* * *}$ & $-0.256^{* * *}$ \\
Urban & HHI & 1988 & $-0.500^{* * *}$ & -0.274 \\
Urban & HHI & 1992 & -0.100 & -0.198 \\
Urban & HHI & 1996 & -0.118 & $-0.923^{* * *}$ \\
Urban & HHI & 1999 & $-0.848^{* * *}$ & $-1.364^{* * *}$ \\
Urban & CR3 & 1988 & $-0.188^{* * * *}$ & -0.082 \\
Urban & CR3 & 1992 & $-0.114^{* *}$ & -0.087 \\
Urban & CR3 & 1996 & -0.063 & $-0.317^{* * *}$ \\
Urban & CR3 & 1999 & $-0.586^{* * *}$ & $-0.365^{* * *}$ \\
\hline
\end{tabular}

$*, * *$, and $* * *$ indicate values that are significantly different from zero at the $0.10,0.05$ and 0.01 levels, respectively. 
Table 10

Estimated Effects of State and Local Concentration on Savings Account Deposit Interest Rates

\begin{tabular}{l|l|l|l|l}
\hline \multicolumn{1}{c|}{ Sample } & $\begin{array}{c}\text { Concentration } \\
\text { measure }\end{array}$ & Year & $\begin{array}{c}\text { Coefficient on } \\
\text { local } \\
\text { concentration }\end{array}$ & \multicolumn{1}{|c}{$\begin{array}{c}\text { Coefficient on } \\
\text { state } \\
\text { concentration }\end{array}$} \\
\hline Full & HHI & 1988 & $-0.084^{*}$ & -0.115 \\
Full & HHI & 1992 & $-0.167^{* * *}$ & $-0.518^{* * *}$ \\
Full & HHI & 1996 & -0.015 & $-0.298^{*}$ \\
Full & HHI & 1999 & -0.069 & $-0.832^{* * *}$ \\
Full & CR3 & 1988 & $-0.146^{* * *}$ & 0.035 \\
Full & CR3 & 1992 & $-0.241^{* * *}$ & $-0.128^{* * *}$ \\
Full & CR3 & 1996 & $-0.179^{* * *}$ & -0.020 \\
Full & CR3 & 1999 & $-0.127^{* *}$ & $-0.241^{* * *}$ \\
Urban & HHI & 1988 & $-0.385^{* *}$ & -0.098 \\
Urban & HHI & 1992 & $-0.351^{* *}$ & $-0.710^{* * *}$ \\
Urban & HHI & 1996 & $-0.648^{* * *}$ & 0.120 \\
Urban & HHI & 1999 & $-0.934^{* * *}$ & 0.175 \\
Urban & CR3 & 1988 & $-0.210^{* * * *}$ & -0.025 \\
Urban & CR3 & 1992 & $-0.235^{* * *}$ & $-0.314^{* * *}$ \\
Urban & CR3 & 1996 & $-0.354^{* * *}$ & 0.001 \\
Urban & CR3 & 1999 & $-0.428^{* * *}$ & 0.049 \\
\hline
\end{tabular}

$*, * *$, and $* * *$ indicate values that are significantly different from zero at the $0.10,0.05$ and 0.01 levels, respectively. 